\title{
The Effect of Grammar Teaching Methods on Students' Writing Skill
}

\author{
Fadiel Mohammed Musa \\ Ph.D., Assistant Professor \\ Department of English Language \\ Nahda College \\ Omdurman, Khartoum, Sudan \\ fadielmoosa@yahoo.com
}

\begin{abstract}
This study investigates the effect of grammar teaching methods on students' writing skill in secondary level. The study was based on action research, carried out in the academic year 2017 in one of Sudanese secondary schools. The participants were in second year. They studied English for the same number of years (6 years). The study followed two different methods of grammar teaching: 1) grammar in 'context' and 2) in 'isolation' to assess which method is more beneficial for English learners to write grammatical error-free composition. Students were divided into two groups: control and experimental groups.For the purpose of high measurement, participants in the two groups sat for apre English test on writing. The results showed that P-value of T-test (0.567) was greater than significant level (0.05) which means there was no statistical difference between experimental and control groups in the pre-test. Then the experiment was run; teaching the two groups using different methods. The control group was taught grammarin isolation method; where experimental group was taught grammar in context.Instructions lasted for two months and the two groups had the same writing test. The results indicated that P-value of T-test (0.000) was less than significant level
\end{abstract}


(0.05) which means there was statistical difference between experimental and control in post-test. Finding showed that: teaching grammar 'in context' helps students to produce better writing than teaching grammar 'in isolation'.

Keywords: control group; experimental group; grammar in isolation; grammar in context; writing

\section{0. Introduction}

Grammar plays a vital role in writing because those grammatically correct essays could be understood easily. Ellis (2006),states that if grammar teaching is not focused on, the learners could produce understandable and meaningful utterances, but they lack accuracy. On the other hand, Krashen (1982), claims that there is no relationship between grammar study and writing.

This study aims to investigate the correlation between grammatical error-free writing production and grammar teaching methods. Two familiar grammar teaching methods were tested: teaching grammar 'in context' and 'in isolation' to.Hence, the researcher decided to conduct this study to solve problems encountered teachers in classroomsto help students to master grammar when they write their texts.

\section{2. Background}

The study is based on $\mathrm{PhD}$ research conducted by the researcher in 2017. The researcher was teaching students foundation courses for the new college intake.It was noticeable that even students could understand rules of English grammar, there were many grammatical mistakes in their writing; i.e., though their theoretical knowledge of grammar was quite acceptable, there were problems in writing grammatically correct sentences. For instance, when students spoke or wrote, the listener or the reader could not be sure about when those events spoken or written about had happened. This case was interrogated by the 
researcher "why though students knew grammar rules well, they could not apply this knowledge of rules when they wrote essays". To answer this question, this study was designed using action research method to diagnose the problem.

\section{3. Questions of the Study}

There is strong relation between grammar knowledge and students' writingaccuracy.This paper triesto find out:(1)Howdoes teaching grammar as set of rules (in isolation) affect students' writing skill?and(2) To what extent does teaching grammar 'in context' help students to write accurate sentences?

\section{4. Significance of the Study}

Writing is a leading cause to learners' academic success in secondary and tertiary levels.This research paper was designed to describe, explain and validaterelation betweengrammar teaching methods and accurate writing. The study focuses on grammar teaching methods to find out which one is more effective in helping students to write essays with minimum grammatical errors and mistakes. Furthermore, theoutcomesof the study couldhelp to find solution to writing problems in classroom and contributes to improvement of students' writing skill.

\section{Literature Review}

In its simplest meaning, writing is the art of expressing thoughts by combining words together and writing them down for some purposes, such as for readers or for someone to assess. Grammar is the rule of language that helps writer to put words together to write correct sentences; it is like glue that fixes parts of the content.

\section{1. Good Writing Strategies}

Writing strategies known as conscious methods followed by the writer. To motivate students, teacher start writing lessons using techniques like: pictures, drawings, outlines, tables, graphs, etc.... to 
help students practice writing using their ideas, interaction with the surrounding environment that pictures and drawings provide.

To figure out strategies lead to good writing,writers should be aware of their audience (readers), the purpose of their text, as well as how the text is organized. In addition, good writers presumably are those who write clear ideas, discuss opinions with effective information, purposeful and avoid grammatical mistakes. On the other hand, unskilled L2 writers are engaged in syntactic and layout of their texts.

It worth mentioning herethe two concepts: Cohesion and Coherence. The term 'Cohesion' refers to connectivity in a text, while the term 'Coherence'refers to how easy to understand writing. Writers need both cohesive devices to link sentences to be understood.For instance, a text may be cohesive (grammatically correct) such as"The ship left the airport. Fortunately, another ship was flying later." These two sentences are incoherent (though they are grammatically correct) because they are meaningless since nothing relates 'ship, airportand 'flying'. A text is cohesive if its elements are linked together (grammar) and coherent when it makes sense. It should be clear to students that cohesion and coherence are necessary for good writing.

Nevertheless, good writing does not mean writing complex sentences, but means acceptable use of grammar. According to Robertson (2000) the variety of words, not the quantity, determines the quality of wring.Killogg (1994: p. 1 - 21) claims that "ideas should ideally precede words".

From cognitive theorists' point of view knowledge is important in starting writing 'I see what I say' reveals that understanding is crucial for writing. Killogg (2008: 2) points out that "Thinking is so closely linked to writing ... that the two are practically twins."

\section{2. Guided and Free Writing}

In the past there were two types of compositions taught and tested in Sudan Secondary Certificate Examinations (SSCE); guided and free compositions, but now there is only one 
composition; guided composition.Ali (2002), states that the guided composition was rooted back to the Audio-lingual Approach, which dominated teaching in the 1960s, where language learning was aimed at teaching speaking, but writing was a secondary activity. The guided composition is intended to consolidate the idea of an error-free activity in language (L2) which may be influenced by L1 interference. Here the teachers were keen in correcting the piece of writing because the aim was to practice language form. Teachers provided controlled questions for the students to answer. This type of composition was advantageous because it helped students to use grammar correctly as the aim was accuracy in the Audio-lingual Approach. But, generally guided composition is less authentic and more objective type of writing.

On the other hand, the idea behind giving students free composition is that writing is not just to achieve a learning process, but writing is more important than this. Writing free composition is an approach to creativity. In free composition students intend to write as much as they can to build fluency and generating thoughts to develop competency. The students are given topics they have experienced before, e.g., a journey, holidays, hometown etc....Teachers guide students by asking questions such as what do you mean by this? Can you give more explanation? Do you think that these ideas are related to each other? Teachers are concerned with the content of the text. Free composition helps students to be creative and write as much as they can.

Both types guided and free compositions are advantageous to students learning L2 for accuracy, and fluency.

\section{3. Feedback}

Feedback includes checking content, grammar errors, cohesion, spelling mistakes sentence structure etc.... Feedback can be in form of direct correction, highlighting, face-to-face or codes. 
Hyland and Hyland (2006), state that feedback forms a key element of students' growing control over composing skills. Any way for EFL students,grammar feedback is necessary to achievegood level of accuracy in the target language.

\section{3. 1.Teacher's Feedback}

Errors and mistakes are now seen as signs of learning process. They are not signs of failure (Marie Paul 1989). But to what extend do teachers respond when they give students feedback? Will they correct every mistake or they choose some particular areas only? There is no consensus on specific procedure that teachers follow, but teachers' feedback is always expected by the students. In a study of a group of EFL students at a Japanese University, Truscott (2007) mentions that students significantly gained from the teachers' feedback, e. g.: that used explicit correction, coded correction, highlighting and marginal count of errors in each time. Teachers' feedback could be written or they can be face-to-face with students if there is available time and place.

\section{3. 2. Peer feedback}

Learners also can benefit from each other because a partner is always available in the classroom and even outside. Partnership is necessary for studying L2 since language is a social activity that needs someone to talk to. Hence; partners can help each other and give feedback during pre- and post-writing of composition discussions. Hyland (2006), points out that peer response is an important support for the drafting and redrafting of process approaches to writing. In addition to that, peer feedback considers partners as readers or audience who evaluate them before submitting written work to teachers.

\section{4. Teaching Grammar}

Teachers and educators agree on importance of grammar teaching. Many analysts now argued that critics against grammar instructions have been unsuccessful. For example, Ellis (2006), states that if grammar teaching is not focused on, the learners could produce understandable utterances. Liviero 
(2014), points out that following communicative methodology only proved to be unsuccessful. Weaver (1996), states that teachers should teach grammar to the minimum for the sake of a maximum meaning focus.Nunan (1998), states that without grammar, speech is meaningless.

But, which method should teachers adapt when they teach grammar? Nunan (1993), states that because grammar in isolation is related to teaching sentences out of context, learners are denied the opportunity of seeing the systematic relationships that exist between form, meaning and use.

According to Nunan (1998), grammar 'in context' is related to reality in any targeted language, learn how to form structures correctly and how to communicate meaning.

\subsection{Related Studies}

Mohite (2014), investigated the writing strategies of EFL Polish students used when they wrote composition. The findings of the study were:

I) Students were generally not aware of the compositional aspect of the L2 writing. They were only concerned with their level of grammatical and lexical competence.

2) Peer collaboration in writing in English was not utilized effectively in the classroom practice.

These two findings explainreasonsbehind students' problemand struggle with their English writing.They lacked understanding of compositional aspect of the English writing and they did not view their English written text as a means of communication.

Abdul-Rahman (2009), conducted an experiment at University of Sunderland to compare native (British) and non-native (Chinese and Libyans) learners' academic writing strategies in higher education. The aim of the study was to compare similarities and differences in strategies employed by the three groups (British, Libyans, and Chinese). The researcher utilized two tools: questionnaire and interviews.302 studentsparticipated in answering the questionnaire. Twelve students were involved the interviews: British, Libyan and Mainland Chinese students. 
Findings show thatcultural and educational backgrounds were more significant in writing strategies than differences in writing by gender, nativeand nationality.

Alinte (2013), conducted a research in Romania to investigate the practical ways in which English grammar can be taught to the seventh grade students. The purpose of the research was to investigate the effectiveness of using songs in teaching grammar to second language students. It also sought to explore the effects of song-based grammar instruction on both students' motivation and classroom atmosphere, as well as to assess teachers' perception regarding the use of songs in teaching grammar. The researcher did an experiment over one school semester. 34 students in the seventh grade were assigned as a control group and an experimental group. Both groups were taught by the same teacher and using the same teaching programme with one difference: the control group performed a traditional grammar-based exercise programme, while for the experimental group a song-based practice was used.

Tests, questionnaires and field notes were used to collect data. The experimental group students reported that songs helped them learn more and also increased their level of motivation. The songs had a positive effect on the classroom atmosphere. The students also believed that songs were fun and create a learning environment that encouraged interaction between students and teachers and enabled students to demonstrate and apply newly acquired language knowledge.

\section{Methodology}

The research followed the empirical study because it is more practical. Fifty-two students, who gave their consent to participate, were selected for the study.They were females, aged between 16 and 17, and all had studied English for the same number of years. The respondents were divided into two groups; experimental and control groups.

The students were actively involved in the process throughout the experiment. Both experimental and control group students were taught the same materials based on learning grammar. 
The experimental group students were taught 'grammar in context' and control group was taught using 'grammar in isolation' methods.

\section{1. Procedure}

Firstly, the researcher identified the area of the study and the problematic issue; i.e., writing and grammar teaching. Then, a test was used to collect data.In this pre-test all students in both groups were asked to write three texts not more than 100 words in each one. The topics were including descriptive and narrative writing. The students' writing papers were collected.

Thenthe researcher began teaching the lessons. After two month's instructions, both groups were given the same post-test. Marks of the two tests (pre- and post-tests) were analyzed and compared.

4.Results

4. 1. Results of Pre-test

Table (4. 1) Frequency distribution of the students' pre- test.

\begin{tabular}{|c|c|c|c|c|}
\hline \multirow{2}{*}{ Grour } & \multicolumn{4}{|c|}{ Level } \\
\cline { 2 - 5 } & Excellen & V. good & Good & Poor \\
\hline Experiment & 0 & 0 & 2 & 27 \\
\hline Control & 0 & 0 & 4 & 25 \\
\hline
\end{tabular}

Table (4.1.)shows that, 2 students got good marks and 27 had obtained poor in experimental group in pre-test. Compared to the control group, 4 students got good marks and 25 had obtained poor in the same pre-test.

\section{2.Results of Post-test}

Table (4. 2): Frequency distribution of the students' post- test.

\begin{tabular}{|l|l|l|l|l|}
\hline \multirow{2}{*}{ Group } & \multicolumn{3}{|l|}{ Level } \\
\cline { 2 - 5 } & Excelle & V. good & Good & Poor \\
\hline
\end{tabular}




\begin{tabular}{|c|c|c|c|c|}
\hline Experimental & 4 & 18 & 7 & 0 \\
\hline Control & 0 & 0 & 4 & 25 \\
\hline
\end{tabular}

Table (4. 2) shows the results of the post-test. There are some differences in marks gained by the students in the two groups. Experimental group have done better than the control group students. For example, 4 students got excellent mark, 18 have obtained very good marks and 7 have got good marks in experimental group in the post-test. While 4 students got good marks in the control group and 25 have obtained poor marks in the same post-test. This indicates that demonstrating writing using grammar in context, helped experimental group students to go through the process and showed them how to use language to compose and express themselves in real situations.

Table (4. 3): Differences between experimental and control groups in pre- and post-tests

\begin{tabular}{|l|l|l|l|l|l|}
\hline Test & Group & Mean & Std. Deviation & T-value & P-value \\
\hline \multirow{2}{*}{ Pre-test } & Experimental & 1.93 & 1.223 & -0.576 & 56 \\
\cline { 2 - 5 } & Control & 2.12 & 1.143 & & \\
\hline Post-test & Experimental & 5.86 & 1.903 & 4.333 & 0.000 \\
\cline { 2 - 5 } & Control & 3.85 & 1.488 & & \\
\hline
\end{tabular}

As illustrated in table 4. 3 above: 
1. The P-value of T-test $(0.567)$ is greater than significant level $(0.05)$ that means there is no statistical difference between experimental and control groups in pre-test.

2. The P-value of T-test $(0.000)$ is less than significant level $(0.05)$ that means there is statistical difference between experimental and control in post-test. This means that students in experimental group out performed students in control group.

Conclusions, Findings and Recommendations .3 .4

The present study was designed to determine the relationship between grammar teaching methods and grammatically correct writing texts; i.e., accuracy.Two questions were set: (a) how does teaching grammar as set of rules (in isolation) affect students' writing skill? and (b) to what extent does teaching grammar 'in context' help students to write accurate sentences?The participants were divided into two groups, control and experimental.

To measure this efficiency pre- andpost-testswere used. Data from students' writing were gathered before and after instructions.

After two months of instructions, results showedthat there were a number of important differences between teaching grammar in isolation and grammar in context.Findingsindicateteaching grammar in set of rules (in isolation) only, does not help students to write error-free composition. There was correlation between lack of accuracy in writing and teaching grammar in isolation method.Findings indicate that there were positive effects on students' writings when they were taught through grammar 'in context' method.These findings imply that teaching grammar 'in context' serves at least two aims: grammar knowledge and helps learners to write grammatical accurate texts.

Based on the results of the study, the following points are recommended:

1- It is advisable to teach grammar in context because this helps students to practice the purpose of the language. 
2- It is better to avoid teaching grammar through exercises(grammar in isolation), such as drills or filling in blanks in single sentences. 


\section{References}

- Abdulrahman, A., 2009, Task-based and Grammar-based English Language Teaching, An Experimental Study in Saudi Arabia, The University of New Castle Library

- Ali, A., 2002, A Study of L1 and L2 Writing Processes and Strategies of Arab Learners With Special Reference to Third Year Libyan University Students, University of Newcastle, Department of Education

- Alinte, C., 2013, Teaching Grammar Through Music,The Journal of Linguistic and Intercultural Education 6 (2013): 7-27,159.

- Ellis, R., 2006, Current Issues in the Teaching of Grammar,TESOL Quarterly Vol. 40, N0. 1, March, pp. $83-107$

- Hyland, K., and Hyland, F., Feedback on second language students' writing, Lang. Teach. 39, 77-95, 2006 Cambridge University Press

- Killogg, R. T., 2008, Training Writing Skills: A Cognitive Developmental Perspective, Journal of Writing Research, 1 (1). 1 - 21

- Krashen, S., 1984, Writing Research Theory and Application, Oxford, Pergamon Institute of English

- Liviero, S., 2014, Teachers' Reported Beliefs about the Role of Grammar and Their Observed Pedagogical Practices of Foreign Languages Teaching in English, University of Exeter

- Mohite, M., 2014, AnInvestigation into the English Language Writing Strategies Used by Polish EFL Secondary School Learners, London Metropolitan University

- Nunan, D. 1993. Introducing Discourse Analysis, London: Penguin

- Nunan, D., Teaching Grammar in Context,ELT Journal Vol. 52/ 2 April 1998, Oxford University Press 
- Paule, M., 1989, Signaling Coherence in First and Second Language Academic Writing, University of Lancaster

- Robertson J., 2000, The Effectiveness of a Virtual Role-playEnvironment as a Preparation Activity for Story Writing, University of Edinburgh

- Truscott, J., 2007, The effect of error correction on learners' ability to write accurately, Journal of Second Language Writing 16 (2007) 255-272, National TsingHua University

- Weaver, C., 1996, Teaching Grammar in the Context of Writing, The English Journal (National Council of Teachers of English), (NCTE), Vol. 85. No. 7, pp. 15-25 